\title{
Microarray Analysis of Potential Biomarkers for brachial plexus avulsion caused neuropathic pain
}

\section{Le Wang1, Jie Lao ${ }^{2,3,4}$}

${ }^{1}$ Department of Pediatric Surgery, Ruijin Hospital, Shanghai Jiao Tong University School of Medicine, Shanghai, PR China

${ }^{2}$ Department of Hand Surgery, Huashan Hospital, Fudan University, Shanghai, PR China;

${ }^{3}$ Key Laboratory of Hand Reconstruction, Ministry of Health, Shanghai, PR China;

${ }^{4}$ Shanghai Key Laboratory of Peripheral Nerve and Microsurgery, Shanghai, PR China.

Keywords: Neuropathic pain; Brachial plexus injury; mRNA; Animal model
Abstract
Nerve injury-induced neuropathic pain remains a challenging clinical problem due to a lack of satisfactory treatment. Pain after BPA (Brachial Plexus Avulsion) is resistant to most traditional pain relief treatments due to the lack of understanding of the cellular or molecular mechanism of pain development. The present study aimed to investigate the expression of mRNA in the brachial plexus avulsion neuropathic pain model and analyze 
biological functions. Sprague-Dawley rats were treated with complete brachial plexus avulsion. An animal behavior test was carried out to distinguish the pain group from the control group. In this study, a microarray mRNA assay and reverse transcriptase quantitative polymerase chain reaction (RT-PCR) was conducted. The whole blood was collected from two groups for Microarray mRNA analysis. The predicted mRNA targets were studied by gene ontology analysis and pathway analysis. The PIK3CB, HRAS, and JUN genes were verified by RT-PCR. In total, differentially expressed genes(DEGs) were identified between individuals with or without neuropathic pain (case and control), and A biological processes were enriched. We identified 3 targeted mRNAs, including PIK3CB, HRAS, and JUN, which may be potential biomarkers for BPAcaused NP. The results showed that PIK3CB, HRAS, and JUN gene expression was increased in the control group but decreased in the neuropathic pain group. The PIK3CB gene was part of the Neurotrophin signaling pathway. The function of the HRAS gene was synergetic in the aspect of axon guidance and the Neurotrophin signaling pathway. The JUN gene participates in axon regeneration. These results suggest that PIK3CB, HRAS, and JUN genes might become potential biomarkers for the prediction of and new targets for the prevention and treatment of neuropathic pain after BPA. These findings indicate that mRNA expression changes in the blood may play an important role in the development of NP 
after BPA, which is of theoretical and clinical importance for future research and clinical-treatment strategies.

Keywords: Neuropathic pain; Brachial plexus injury; mRNA; Animal models

\section{Introduction}

Nerve injury-induced neuropathic pain remains an intractable disease due to a lack of satisfactory treatment [9]. In 2017, Palma Ciaramitaro et al. [1] investigate the prevalence of neuropathic pain after traumatic brachial plexus injury. Of the 107 patients enrolled, 69\% had neuropathic pain. Neuropathic pain can significantly impair function, appetite, sleep, mood, and quality of life. Brachial plexus avulsion (BPA) induces a characteristic of pain are allodynia, hyperalgesia, and persistent pain, which is often difficult to cure [10]. The pain may be manifested as burning or pressure. Pain after BPA is resistant to most pain relief treatments the exact molecular mechanisms responsible for this pathology remain unknown[3]. Previous studies demonstrated that the mRNA plays a key role in the development and maintenance of neuropathic pain $[11-13]$. 
Some authors proved that c-Jun plays a vital role in the survival of ventral horn motoneurons in adult mice[4]. At present, there is no literature to prove that the HRAS gene is related to neuropathic pain caused by brachial plexus injury. Previous studies have shown that PIK3CB influences the early development of neuropathy in sensory neurons[2]. The spinal cord plays an important role in the process of central sensitization [14]. Furthermore, we aimed to investigating the mRNA changes of neuropathic pain caused by the brachial plexus avulsion model, thereby providing a novel insight into the mechanism of neuropathic pain.

\section{Material and methods}

\subsection{Animals}

This study was carried out in strict accordance with the recommendations in the Guide for the Care and Use of Laboratory Animals of the National Institutes of Health. The protocol was approved by the Committee on the Ethics of Animal Experiments of the University of Fudan (GB/T 35892-2018). All surgery was performed under sodium pentobarbital anesthesia, and all efforts were made to minimize suffering. The experiments were conducted in male Sprague- Dawley rats $(n=20$, age, eight 
weeks; weight, 200- 250g; supplied by the Department of Laboratory Animal Science, Fudan University, Shanghai, China).

\subsection{Surgery procedure}

All surgical procedures were performed after anesthesia induced by a $1 \%$ sodium pentobarbital solution $(40 \mathrm{mg} / \mathrm{kg}$ body weight). Place the rat prone on a sterilized pad with the head oriented away from the surgeon and the right forepaw abducted and extended. Use the fingertips to locate the clavicle. With a scalpel, make a $1.5 \mathrm{~cm}$ horizontal incision in the skin under the clavicle $2 \mathrm{~mm}$. Use micro-dissecting scissors to separate the skin from the superficial fascia, exposing the pectoralis major muscle. The pectoralis major muscle was cut paralleled with the muscle fibers to expose the brachial plexus, leaving the cephalic vein intact. The subclavian vessels were located and the upper, middle and lower trunks were dissected. In the complete brachial plexus avulsion

(BPA) group $(\mathrm{n}=20)$, the upper, middle, and lower trunk were grasped with forceps and haul out from the spinal cord. The tissue layers were then brought together, and the skin was closed with 4-0 silk sutures (Ethicon), as described previously[7]. 


\subsection{Animal pain tests}

Mechanical allodynia: Mechanical allodynia was assessed by using the von Frey filaments (Stoelting, USA; bending force: 2.0, 4.0, 6.0, 8.0, 10.0, 15.0, and $26.0 \mathrm{~g})$. The filaments were applied to the left forepaw. The threshold was the lowest force that evoked a withdrawal response. Each filament was applied five times. When rats showed at least two withdrawal responses to a filament, the bending force of the filament was defined as the withdrawal threshold.

Cold allodynia: Cold allodynia was assessed by an acetone spray test as described by Choi et al. [8]. $250 \mu$ lacetone was squirted onto the surface of the paw. Neuropathy rats frequently responded with a withdrawal that was clearly exaggerated in amplitude and duration. The withdrawal responses were assessed on a scale of 3-0 points: 3 points, a vigorous response in which the rat licked the paw; 2 points, a response in which the paw has elevated the paw; 1 point, a response in which the paw had little or no weight born on it and 0 points, the paw was not moved[5].

\section{4 mRNA microarray}


The whole blood was collected from the rats. Total RNA was extracted from whole blood using a QIAamp RNA blood mini kit (Qiagen) per the manufacture's instruction. Purified total RNA for each strain used in Affymetrix GeneChip assays (Affymetrix GeneChip Rat Gene 1.0). Microarrays were processed using an Agilent GeneArray Scanner with Affymetrix Microarray Suite version 5.0.0.032 software.

\subsection{Reverse transcription-quantitative polymerase chain} reaction ( $R$ T-PCR) assay

RNA was reverse transcribed into cDNA using Takara PrimeScript RT master mix (RR036A; Takara Biotechnology Co., Ltd., Dalian China). RT-qPCR was performed using an ABI StepOne Plus Real-Time PCR system (Thermo Fisher Scientific, Inc.) and SYBR Premix Ex Taq II master mix (Takara Biotechnology Co., Ltd.) according to the manufacturer's protocol. The reaction system $(10 \mu \mathrm{l})$ consisted of cDNA $(1 \mu \mathrm{l})$, forward primers $(10 \mu \mathrm{M} ; 0.2 \mu \mathrm{l})$, reverse primers $(10 \mu \mathrm{M} ; 0.2 \mu \mathrm{l})$, ROX reference dye $(0.2 \mu 1)$, RNase-free water $(3.4 \mu 1)$, and SYBR-Green mixture $(5 \mu 1)$. The thermocycling conditions were as follows: Initial denaturation, $95^{\circ} \mathrm{C}$ for $30 \mathrm{sec}$, followed by 40 cycles of $95^{\circ} \mathrm{C}$ for $5 \mathrm{sec}$ and $60^{\circ} \mathrm{C}$ for $30 \mathrm{sec}$. Rat actin was used 
as a housekeeping gene. The relative expression of genes was calculated using the $2^{-\Delta \Delta \mathrm{Ct}}$ method.

\subsection{Bioinformatic evaluation.}

GO analysis was applied to analyze the function of the expression genes according to the Gene Ontology, which is the crucial function of NCBI that can organize genes into hierarchical classification and uncover the gene network on the basis of biological process and molecular function.

Pathway analysis was applied to find out the significant pathway of the differential genes according to KEGG, Biocarta, and Reactome. Still, we turn to Fisher's exact test and $\chi^{2}$ test to select the most significant pathway, and the threshold of significance was decided by $P$-value and FDR. The enrichment Re was calculated like the equation above.

\subsection{Statistical analysis}

The

random variance model t-test was adopted to filter the differinitially expressed mRNAs between the control and pain groups using GraphPad 5.0. Following the significance analysis 
and false discovery rate analysis, differentially expressed genes were selected according to their P-values. $\mathrm{P}<0.05$ was considered to indicate a statistically significant difference.

\section{Results}

\section{mRNA microarray}

Animals exhibiting significant decreases in the pain threshold(mechanical threshold decreases from $15 \mathrm{~g}$ pre-surgery to $8 \mathrm{~g}$ post-surgery and allodynia score increases from 0 presurgery to 2-3 post-surgery) were placed in the NP(Neuropathic Pain) group. There were 10 rats do the BPA surgery and 6 rats had neuropathic pain. There were 6 rats in the NP group. The sham-operated animals whose brachial plexus was just dissected but not used were assigned to the control group. There were 10 rats in the control in the control group. 
Table1 The most significant Upregulated Genes or

Downregulated Genes in neuropathic pain group

\begin{tabular}{|c|c|c|c|c|}
\hline Probe set ID & Gene symbol & Gene description & P-value & Trend \\
\hline 10937619 & LOC685774 & Hypothetical protein & 0.0253862 & down \\
\hline 10937311 & Mir448 & microRNA & 0.0380793 & down \\
\hline 10936853 & Midlip1 & MID1 protein & 0.0390031 & down \\
\hline 10934445 & Ogt & GlcNAc transferase & 0.0395949 & down \\
\hline 10929600 & Pde6d & Phosphodiesterase 6D & 0.0389264 & down \\
\hline 10929445 & $\operatorname{Tm} 4 \mathrm{sf} 20$ & transmembrane & 0.0374896 & down \\
\hline 10925373 & Ube2f & $\begin{array}{l}\text { Ubiquitin-conjugating } \\
\text { enzyme E2F }\end{array}$ & 0.0308392 & down \\
\hline 10911048 & Dapk2 & Death-associated kinase 2 & 0.0257355 & down \\
\hline 10908788 & Zbtb44 & $\begin{array}{l}\text { Zinc finger and BTB } \\
\text { domain containing } 44\end{array}$ & 0.0406164 & down \\
\hline 10905558 & Rpl26 & Ribosomal protein L26 & 0.0278983 & down \\
\hline 10714907 & Ifit1 & Interferon-induced & $<1 \mathrm{e}-07$ & up \\
\hline 10886573 & Ifi27 & $\begin{array}{l}\text { Interferon, alpha-inducible } \\
\text { protein } 27\end{array}$ & $<1 \mathrm{e}-07$ & up \\
\hline 10811177 & Ctrb1 & Chymotrysinogen B1 & $<1 \mathrm{e}-07$ & up \\
\hline 10882317 & Isg15 & $\begin{array}{l}\text { ISG } 15 \text { Ubiquitin-like } \\
\text { modifier }\end{array}$ & $<1 \mathrm{e}-07$ & up \\
\hline 10827820 & RT1-T24-4 & $\begin{array}{l}\text { RT1 class I, locus T24, } \\
\text { gene } 4\end{array}$ & $<1 \mathrm{e}-07$ & up \\
\hline 10737262 & Supt $4 \mathrm{~h} 1$ & $\begin{array}{l}\text { Suppressor of Ty4 homolog } \\
1\end{array}$ & $<1 \mathrm{e}-07$ & up \\
\hline 10732592 & Nprls & $\begin{array}{l}\text { Nitrogen permease } \\
\text { regulator-like } 3\end{array}$ & $<1 \mathrm{e}-07$ & up \\
\hline
\end{tabular}




\begin{tabular}{lllll}
\hline 10785144 & Xpo07 & Exportin7 & $<1 \mathrm{e}-07$ & up \\
\hline 10749495 & Lgals3bp & $\begin{array}{l}\text { Lectin, galactoside-binding, } \\
\text { soluble, 3 binding protein }\end{array}$ & $<1 \mathrm{e}-07$ & up \\
& & & \\
10704505 & S1c1a5 & Solute carrier family & $<1 \mathrm{e}-07$ & up \\
& & & \\
& & & \\
& & &
\end{tabular}

Table 2. The Top 20 most significant GO terms in neuropathic pain group

\begin{tabular}{|c|c|c|c|c|}
\hline GO Terms & GO name & Path-count & Enrichment & Trend \\
\hline 0009615 & Response to virus & 84 & 12.30162448 & up \\
\hline 0045087 & $\begin{array}{l}\text { Innate immune } \\
\text { response }\end{array}$ & 93 & 10.69962082 & up \\
\hline 0008150 & Biological process & 1408 & 2.582253877 & up \\
\hline 0043066 & $\begin{array}{l}\text { Negative regulation } \\
\text { of apoptotic }\end{array}$ & 478 & 4.003318056 & up \\
\hline 0042493 & Response to drug & 462 & 3.893443439 & up \\
\hline 0051607 & $\begin{array}{l}\text { Defense response to } \\
\text { virus }\end{array}$ & 96 & 8.371938884 & up \\
\hline 0014070 & $\begin{array}{l}\text { Response to an } \\
\text { organic } \\
\text { compolic } \\
\text { compound }\end{array}$ & 230 & 5.158362344 & up \\
\hline 0008285 & $\begin{array}{l}\text { Negative regulation } \\
\text { of cell proliferation }\end{array}$ & 308 & 4.349059161 & up \\
\hline
\end{tabular}




\begin{tabular}{|c|c|c|c|c|}
\hline 0032355 & $\begin{array}{l}\text { Response to } \\
\text { estradiol stimulus }\end{array}$ & 143 & 6.155591427 & up \\
\hline 0006954 & $\begin{array}{l}\text { Inflammatory } \\
\text { response }\end{array}$ & 189 & 5.264892783 & up \\
\hline 0008150 & Biological process & 1408 & 2.44882276 & down \\
\hline 0006355 & $\begin{array}{l}\text { Regulation of } \\
\text { transcription DNA- } \\
\text { depensent }\end{array}$ & 681 & 2.8479700082 & down \\
\hline 0006351 & $\begin{array}{l}\text { Transcription, } \\
\text { DNA-dependent }\end{array}$ & 640 & 2.862061601 & down \\
\hline 0006886 & $\begin{array}{l}\text { Intracellular protein } \\
\text { transport }\end{array}$ & 167 & 4.838991083 & down \\
\hline 0015031 & Protein transport & 271 & 3.777150973 & down \\
\hline 0006412 & Translation & 384 & 3.226834158 & down \\
\hline 0045944 & $\begin{array}{l}\text { Positive regulation } \\
\text { of transcription } \\
\text { from RNA } \\
\text { polymerase II } \\
\text { promoter }\end{array}$ & 715 & 2.411148564 & down \\
\hline 0000122 & $\begin{array}{l}\text { Negative regulation } \\
\text { of transcription } \\
\text { from RNA } \\
\text { polymerase II } \\
\text { promoter }\end{array}$ & 499 & 2.699103242 & down \\
\hline 0015986 & $\begin{array}{l}\text { ATP synthesis } \\
\text { coupled proton } \\
\text { transport }\end{array}$ & 19 & 14.17739493 & down \\
\hline 006302 & $\begin{array}{l}\text { Double-strand brake } \\
\text { repair }\end{array}$ & 48 & 7.856639688 & down \\
\hline
\end{tabular}

GO: Gene Ontology; Count: enriched gene numbers in each term. 
Table 3. The Top 20 most significant enriched KEGG pathways

\begin{tabular}{|c|c|c|c|c|}
\hline KEGG Term & Pathname & $\begin{array}{l}\text { Path } \\
\text { gene } \\
\text { count }\end{array}$ & Enrichment & Trend \\
\hline 04145 & Phagosome & 196 & 7.810555227 & up \\
\hline 05168 & Herpes simplex infection & 218 & 6.320100652 & up \\
\hline 01100 & Metabolic pathways & 1272 & 2.768080422 & up \\
\hline 04612 & $\begin{array}{l}\text { Antigen processing and } \\
\text { presentation }\end{array}$ & 98 & 9.372666273 & up \\
\hline 05203 & Viral carcinogenesis & 239 & 5.284379834 & up \\
\hline 05169 & $\begin{array}{l}\text { Epstein-Barr virus } \\
\text { infection }\end{array}$ & 232 & 5.278858016 & up \\
\hline 04062 & $\begin{array}{l}\text { Chemokine signaling } \\
\text { pathway }\end{array}$ & 180 & 5.953378762 & up \\
\hline 04670 & $\begin{array}{l}\text { Leukocyte } \\
\text { transendothelial } \\
\text { migration }\end{array}$ & 119 & 7.075444147 & up \\
\hline 04516 & Viral myocarditis & 110 & 7.30641939 & up \\
\hline 04144 & Endocytosis & 236 & 4.702880923 & up \\
\hline 00190 & $\begin{array}{l}\text { Oxidative } \\
\text { phophorylation }\end{array}$ & 162 & 7.981348255 & down \\
\hline 05010 & Alzheimer's disease & 214 & 6.545451489 & down \\
\hline
\end{tabular}




\begin{tabular}{lllll}
\hline 05012 & Parkinson's disease & 164 & 6.898512897 & down \\
01100 & Metabolic pathways & 1272 & 2.625938872 & down \\
05016 & Huntingtin's disease & 219 & 4.920009198 & down \\
04120 & Ubiquitin mediated & 136 & 5.149730216 & down \\
& proteolysis & & & \\
04141 & Protein processing in the & 165 & 4.571135819 & down \\
& endoplasmic reticulum & & & \\
04110 & Cell cycle & 126 & 5.130866735 & down \\
05168 & Herpes simplex infection & 218 & 3.706933536 & down \\
05164 & Influenza A & 177 & 3.956854855 & down \\
\hline
\end{tabular}

KEGG: Kyoto Encyclopedia of Genes and Genomes

To functionally investigate a possible link between mRNA expression and the brachial plexus injury neuropathic pain, the differential expression of mRNA in the neuropathic pain and control group was analyzed. The whole blood was harvest from the rat after 2 weeks. The expression of 2717 mRNAs was detected between the pain and control group according to the changes: down and up. By contrast to the control group and the pain group, 1154 mRNAs exhibited decreased expression, and 1563 mRNAs exhibited increased expression. The most significant top 10 upregulated or downregulated genes are shown in Table 1.

We have found $621 \mathrm{GO}$ terms with the $\mathrm{P}$-value $<0.05$. The top 20 GO terms, ranked by P-value, were shown in table 2. Most of 
the enriched terms were about inflammatory processes involved in protein modification and regulation of biological processes. The result was similar to the GO analysis.

To further investigate the functions of DEGs, we did a KEGG pathway analysis. The top 20 pathways were shown in table 3 . The most significantly enriched pathways were Metabolic pathways, antigen processing and presentation, and Herpes simplex infection.

\section{PCR verification}

We aimed to explore the mechanism of neuropathic pain after brachial plexus avulsion and find nerve-related mRNAs. Therefore, we mainly focused on the differentially expressed genes(DEGs) dysregulated only in the neuropathic pain groups. The three nerve-related mRNAs (Pik3cb, Hras, and Jun genes) exhibited decreased expression in the neuropathic pain group.

To validate the microarray results, RT-qPCR was performed for Pik3cb, Hras, and Jun genes. It was found that the relative expression of 3 mRNA among them was significantly altered, which coincided with the results of the microarray (Figure 1 ).

Figure 1: Relative expression of differentially expressed mRNA 
in rat whole blood in the microarray. (a) Hras were significantly down-regulated in neuropathic pain group versus the control group after 2 weeks. (b) Jun was significantly down-regulated in neuropathic pain group versus the control group after 2 weeks. (c) Pik3cb were significantly down-regulated in neuropathic pain group versus the control group after 2 weeks. Data are presented as mean $\pm \mathrm{SE}, * \mathrm{p}<0.05$. NP group: Neuropathic Pain group

\section{Bioinformatics analysis of the diff-reg mRNA}

The Pik3cb, Hras, and Jun genes were intersection genes, which were involved in neuropathic pain according to GO and pathway analyses. The results showed that Pik3cb, Hras, and Jun gene expression was high in the control group but was low in the neuropathic pain group. The function of the Hras gene was synergetic in the aspect of axon guidance and the Neurotrophin signaling pathway. The Jun gene function was axon regeneration. The low expression of two genes in the neuropathic pain group was revealed that neuropathic pain is unfavorable for nerve 
regeneration.

\section{Discussion}

Brachial Plexus Avulsion(BPA) has been demonstrated to be a polygenic disease and its pathogenic mechanism is associated with changes in many genes. In this study, we have used microarray to identify differentially expressed genes(DEGs) and activated signaling pathways in association with BPAinduced neuropathic pain(NP) in a rat BPA model. We showed that Jun, HRAS, and PIK3B were the nerve-related downregulated DEG.

Our results are consistent with that of previous studies[7]. Although the precise roles of the three marker genes in BPA- 
induced NP are not completely understood, our data highlighted the diagnostic and treatment potential of this disease.

It will be very interesting to further this study into BPA patients. Microarray technology can be reliable and useful for identifying novel targets for clinical diagnostic and therapeutic approaches. This technology can be used in pancreatic cancer and renal clear cell carcinoma for diagnosis and effective therapy[15,17].

We found that three genes expressed decreased and were related to nerve regeneration. Some authors proved that the downregulation of c-Jun gene expression is not conducive to the survival of motoneurons. HRAS might serve specific roles in the development and maintenance of nervous tissues[6]. In our study, the Metabolic signaling pathway and Phagosome signaling pathway are involved in BPA, which play a very important role in BPA-induced NP. In the peripheral nervous system, recent studies suggested that the nerve-related gene plays an important role in neuropathic pain after spinal cord injury[16]. Some authors suggested that there is a high possibility of neuropathic pain caused by nerve damage[18,19]. The transcriptome changed play an important role in neuropathic pain[13]. So our research is meaningful and feasible. Ji-An Yang et al[20] proved that Jun is 
a potential indicator for neuropathic pain. Despite increasing knowledge and ongoing study, the precise molecular mechanisms of neuropathic pain caused by brachial plexus injury remain largely unknown. Numerous studies show a significant modification of gene expression as a consequence of nerve injury. A study by Timo et al reported that miRNAs-494, -720,-690, and -668 showed the highest signal intensities in the rat spinal cord[21]. The exosomes with $\mathrm{Ccl} 3$ can be efficiently detected in peripheral blood. Guan Zhang et al proved that $\mathrm{Ccl} 3$ can be used as a potential prognostic target for the diagnosis and treatment of spinal cord injury-induced chronic neuropathic pain in clinical applications. The microarray analysis of DEGs and pathway indifferent section by GO and KEGG suggests another method and strategy research the target gene and pathway of nerve-related disease[22].

In summary, our studies indicated that Jun, HRAS, and PIK3B might serve a significant role in neuropathic pain and nerve regeneration. we demonstrated that microarray. The three nerve-related genes were downregulated in the spinal cord in NP rats after brachial plexus avulsion. Furthermore, KEGG analysis found that Metabolic pathways with significance were identified. These results strongly suggest that neuropathic pain 
may attenuate nerve regeneration via inhibition of neurotrophin signaling pathway and axon guidance pathway, which is of theoretical and clinical importance for future research and clinical-treatment strategies. Several limitations should be acknowledged in our study. First, the sample size was relatively small. Besides, the results were all base on a rat model. In the future, we will perform some more in-depth studies around nerverelated genes.

\section{Conflicts of interest}

The authors declare no conflict of interest

Supporting information

Table1. The most significant Upregulated Genes or Downregulated Genes in neuropathic pain group $(\mathrm{DOCX})$

Table 2. The Top 20 most significant GO terms in neuropathic pain group (DOCX)

Table 3. The Top 20 most significant enriched KEGG pathways 


\section{$(\mathrm{DOCX})$}

Figure 1: Relative expression of differentially expressed mRNA in rat whole blood in the microarray. (a) Hras were significantly down-regulated in the neuropathic pain group versus the control group after 2 weeks. (b) Jun was significantly down-regulated in the neuropathic pain group versus the control group after 2 weeks. (c) Pik3cb were significantly down-regulated in the neuropathic pain group versus the control group after 2 weeks. Data are presented as mean $\pm \mathrm{SE}, * \mathrm{p}<0.05$. NP group: Neuropathic Pain group

(TIF)

\section{Acknowledgments}

This work was supported by the Ministry of Science and The technology of China (973 Program Grant 2014CB542204). 


\section{Author Contributions}

Conceptualization: Jie Lao, Le wang.

Data curation: Le wang

Formal analysis: Jie Lao, Le wang.

Funding acquisition: Jie Lao

Investigation: Jie Lao, Le wang.

Methodology: Jie Lao, Le wang.

Project administration: Jie Lao, Le wang.

Resources: Jie Lao, Le wang.

Supervision: Jie Lao

Validation: Le wang.

Writing - original draft: Le wang.

Writing - review \& editing: Jie Lao.

\section{References}

[1] Ciaramitaro P, Padua L, Devigili G, Rota E, Tamburin S, Eleopra R, Cruccu G, Truini A; Neuropathic pain special interest group of the Italian Neurological Society. Prevalence of Neuropathic Pain in Patients with Traumatic Brachial Plexus Injury: A Multicenter Prospective Hospital-Based Study. Pain Med. 2017 Dec 1;18(12):2428-2432. doi: 10.1093/pm/pnw360. PMID: 28340085.

[2] Elzinga S, Murdock BJ, Guo K, Hayes JM, Tabbey MA, Hur J, Feldman EL. Toll-like receptors and inflammation in metabolic neuropathy; a role in early versus late disease? Exp Neurol. 2019 Oct;320:112967. doi: 10.1016/j.expneurol.2019.112967. Epub 2019 May 28. PMID: 31145897; PMCID: PMC6708507.

[3] Inoue K, Tsuda M. Microglia in neuropathic pain: cellular and molecular mechanisms and therapeutic potential. Nat Rev Neurosci. 2018 Mar;19(3):138- 
[4] Li YQ, Song FH, Zhong K, Yu GY, Zilundu PLM, Zhou YY, Fu R, Tang Y, Ling ZM, Xu X, Zhou LH. Pre-Injection of Small Interfering RNA (siRNA) Promotes c-Jun Gene Silencing and Decreases the Survival Rate of AxotomyInjured Spinal Motoneurons in Adult Mice. J Mol Neurosci. 2018 Jul;65(3):400-410. doi: 10.1007/s12031-018-1098-y. Epub 2018 Jul 10. PMID: 29992498.

[5] Liu Y, Wang L, Lao J, Zhao X. Changes in microRNA expression in the brachial plexus avulsion model of neuropathic pain. Int J Mol Med. 2018 Mar;41(3):1509-1517. doi: 10.3892/ijmm.2017.3333. Epub 2017 Dec 19. PMID: 29286067; PMCID: PMC5819907.

[6] Waldron AL, Cahan SH, Francklyn CS, Ebert AM. A single Danio rerio hars gene encodes both cytoplasmic and mitochondrial histidyl-tRNA synthetases. PLoS One. 2017 Sep 21;12(9):e0185317. doi: 10.1371/journal.pone.0185317. Erratum in: PLoS One. 2018 Jan 2;13(1):e0190757. PMID: 28934368; PMCID: PMC5608375.

[7] Wang L, Yuzhou L, Yingjie Z, Jie L, Xin Z. A new rat model of neuropathic pain: complete brachial plexus avulsion. Neurosci Lett. 2015 Mar 4;589:52-6. doi: 10.1016/j.neulet.2015.01.033. Epub 2015 Jan 14. PMID: 25596440.

[8] Yoon C, Wook YY, Sik NH, Ho KS, Mo CJ. Behavioral signs of ongoing pain and cold allodynia in a rat model of neuropathic pain. Pain. 1994 Dec;59(3):369-376. doi: 10.1016/0304-3959(94)90023-X. PMID: 7708411.

[9] Zhang K, Wang J, Xi H, Li L, Lou Z. Investigation of Neuroprotective Effects of Erythropoietin on Chronic Neuropathic Pain in a Chronic Constriction Injury Rat Model. J Pain Res. 2020 Nov 30;13:3147-3155. doi: 10.2147/JPR.S285870. PMID: 33311994; PMCID: PMC7725095.

[10] Zhou Y, Liu P, Rui J, Zhao X, Lao J. The clinical characteristics of neuropathic pain in patients with total brachial plexus avulsion: A 30-case study. Injury. 2016 Aug;47(8):1719-24. doi: 10.1016/j.injury.2016.05.022. Epub 2016 May 18. PMID: 27287738.

[11] Meng C, Yang X, Liu Y, Zhou Y, Rui J, Li S, Xu C, Zhuang Y, Lao J, Zhao $\mathrm{X}$. Decreased expression of $\operatorname{lncRNA}$ Malat1 in rat spinal cord contributes to neuropathic pain by increasing neuron excitability after brachial plexus avulsion. J Pain Res. 2019 Apr 23;12:1297-1310. doi: 10.2147/JPR.S195117. PMID: 31114309; PMCID: PMC6497903.

[12] Wang Y, Ye F, Huang C, Xue F, Li Y, Gao S, Qiu Z, Li S, Chen Q, Zhou H, Song Y, Huang W, Tan W, Wang Z. Bioinformatic Analysis of Potential Biomarkers for Spinal Cord-injured Patients with Intractable Neuropathic Pain. Clin J Pain. 2018 Sep;34(9):825-830. doi: 10.1097/AJP.0000000000000608. PMID: 29547407; PMCID: PMC6078488.

[13] Cao S, Yuan J, Zhang D, Wen S, Wang J, Li Y, Deng W. Transcriptome Changes In Dorsal Spinal Cord Of Rats With Neuropathic Pain. J Pain Res. 2019 Nov 8;12:3013-3023. doi: 10.2147/JPR.S219084. PMID: 31807058; PMCID: 


\section{PMC6850707.}

[14] Sandkühler J. Models and mechanisms of hyperalgesia and allodynia. Physiol Rev. 2009 Apr;89(2):707-58. doi: 10.1152/physrev.00025.2008. PMID: 19342617.

[15] Shinjo K, Hara K, Nagae G, Umeda T, Katsushima K, Suzuki M, Murofushi Y, Umezu Y, Takeuchi I, Takahashi S, Okuno Y, Matsuo K, Ito H, Tajima S, Aburatani H, Yamao K, Kondo Y. A novel sensitive detection method for DNA methylation in circulating free DNA of pancreatic cancer. PLoS One. 2020 Jun 10;15(6):e0233782. doi: 10.1371/journal.pone.0233782. PMID: 32520974; PMCID: PMC7286528.

[16] Lin M, Huang W, Kabbani N, Theiss MM, Hamilton JF, Ecklund JM, Conley YP, Vodovotz Y, Brienza D, Wagner AK, Robbins E, Sowa GA, Lipsky RH. Effect of CHRFAM7A $\triangle 2 \mathrm{bp}$ gene variant on secondary inflammation after spinal cord injury. PLoS One. 2021 May 6;16(5):e0251110. doi: 10.1371/journal.pone.0251110. PMID: 33956875; PMCID: PMC8101719.

[17] Han M, Yan H, Yang K, Fan B, Liu P, Yang H. Identification of biomarkers and construction of a microRNA-mRNA regulatory network for clear cell renal cell carcinoma using integrated bioinformatics analysis. PLoS One. 2021 Jan 12;16(1):e0244394. doi: 10.1371/journal.pone.0244394. PMID: 33434215; PMCID: PMC7802940.

[18] Chiba M, Higuchi K, Kondoh T, Echigo S (2008) Clinical picture of neuropathic trigeminal pain provoked

by dental treatment. Journal of the Japanese Stomatological Society. 2008; 57(4):37984. PMID: 2009062023.

[19] Honjo Y, Fujita Y, Niwa H, Yamashita T. Increased expression of Netrin-4 is associated with allodynia in a trigeminal neuropathic pain model rats by infraorbital nerve injury. PLoS One. 2021 Apr 29;16(4):e0251013. doi: 10.1371/journal.pone.0251013. PMID: 33914819; PMCID: PMC8084253.

[20] Yang JA, He JM, Lu JM, Jie LJ. Jun, Gal, Cd74, and C1qb as potential indicator for neuropathic pain. J Cell Biochem. 2018 Jun;119(6):4792-4798. doi: 10.1002/jcb.26673. Epub 2018 Mar 7. PMID: 29331040.

[21] Brandenburger T, Castoldi M, Brendel M, Grievink H, Schlösser L, Werdehausen R, Bauer I, Hermanns H. Expression of spinal cord microRNAs in a rat model of chronic neuropathic pain. Neurosci Lett. 2012 Jan 11;506(2):281-6. doi: 10.1016/j.neulet.2011.11.023. Epub 2011 Nov 23. PMID: 22138088.

[22] Zhang G, Yang P. Bioinformatics Genes and Pathway Analysis for Chronic Neuropathic Pain after Spinal Cord Injury. Biomed Res Int. 2017;2017:6423021. doi: 10.1155/2017/6423021. Epub 2017 Oct 15. PMID: 29164149 ; PMCID: PMC5661087. 
bioRxiv preprint doi: https://doi.org/10.1101/2021.08.05.455327; this version posted August 5, 2021. The copyright holder for this preprint (which was not certified by peer review) is the author/funder, who has granted bioRxiv a license to display the preprint in perpetuity. It is made available under aCC-BY 4.0 International license. 
a

Hras relative expression(axon guidance)

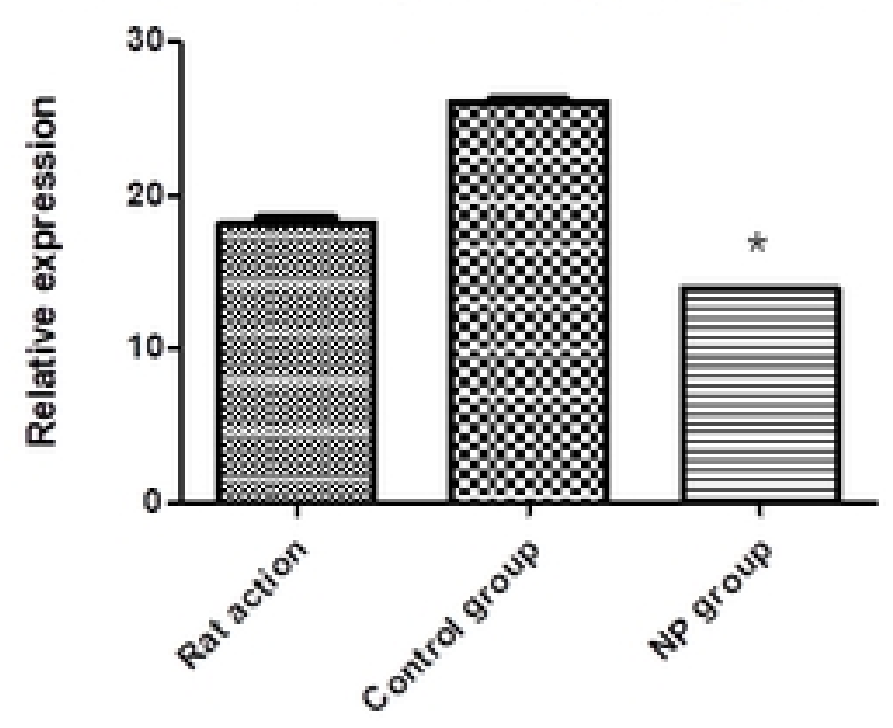

C

Pik3cb relative expression(Neurotrophin signaling pathway)

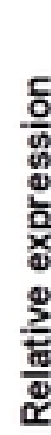

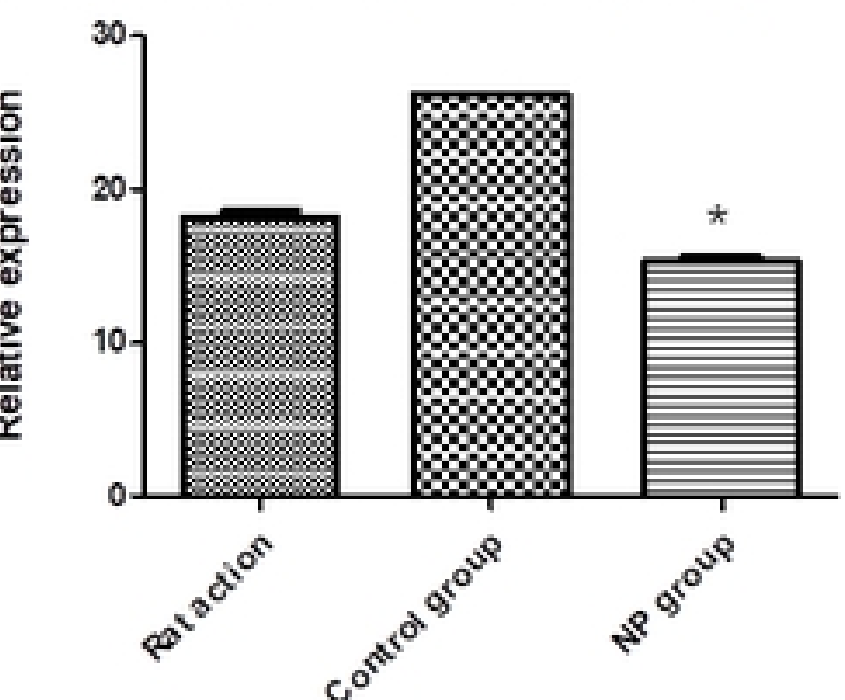

Figure 1
Jun relative expression(axon regeneration)

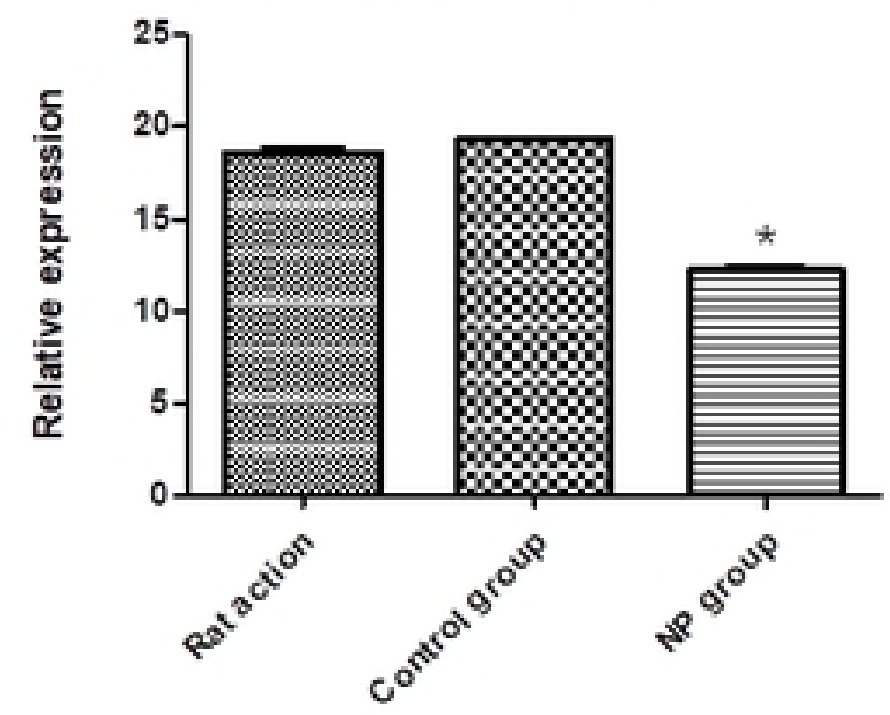

